\title{
Living on the Coke side of thirst: The Coca-Cola Company and responsibility for water shortage in India
}

\author{
Denise Gül Holzendorff \\ Technical University of Applied Sciences Wildau
}

\begin{abstract}
Making soft drinks requires fresh water - lots of it, and not only for the bottled content but more for the industrial production process. Water sourcing has become a critical issue for The Coca-Cola Company, the world's leading beverage manufacturer, particularly for its India subsidiary. Coca-Cola India has come under intense criticism for competing for ground water with agriculture and household use in water-deprived regions. For some ten years, its bottling plants have been accused of stealing water from surrounding villages. Evidence suggests the company has indeed been somewhat responsible for water shortages, and Indian courts have held the firm liable, even going so far as closing a plant and demanding millions of dollars in compensation for damages. Not only Coca-Cola India but also its parent, The Coca-Cola Company based in Atlanta, have recognized the water issue as a major social and environmental CSR challenge with the potential to harm the international reputation and the international brand. Coca-Cola has been investing in innovative technology to reduce its water use and is engaging in community outreach campaign to repair and improve its stakeholder relations. The article outlines the water dilemma and analyzes the firms' global and local responses.
\end{abstract}

Keywords: corporate social responsibility (CSR), water management, India, food and drink industry

Author: Denise Gül Holzendorff is working on her Master's thesis in the M.A. in European Management program at Technical University of Applied Sciences Wildau.

\section{Introduction}

India is not generally a country with water scarcity. It has areas with no scarcity problem and areas where the problem is large. Most fresh water is used for agriculture (IWMI, p.8). It is reasonable that the presence of a multinational enterprise which operates 57 bottling plants in India comes under criticism when it becomes clear that it effectively competes with farming and households for water resources in water-poor regions. The critical point may not be easy for a European reader to comprehend unless it is understood that typically, a bottling plant does not pay a local water utility to supply water like it would do here. Instead, the plant would drill its own wells and use ground water for free. It would install high-performing wells and pumps, while in the agricultural neighborhood of the plant, farmers and villagers would still rely on very simple self-dug wells. Clearly, the plant has a great technical advantage. When water supply conditions get worse, farmers' wells may dry up while the plant still has enough. It is easy, then, to see that the potential for conflict is great.

In a decade of controversy, the issue has gone beyond India's borders. News reports and activism by international nongovernmental organizations (NGOs) - especially green, development and humanitarian groups, globalization critics, and the global right-to-water movement, which is critical of private corporations in water management - have continuously put pressure on Coca-Cola as a global entity and brand. As a matter of corporate social responsibility, the involvement of Coca-Cola with water problems in India has become a global symbol and an issue for world headquarters management to deal with.

In theory, only Coca-Cola India (CCI) and its licensed bottling partners are responsible for finding answers to the regional dilemmas. But CCI, although operating quite independently, is a wholly-owned subsidiary of The Coca-Cola Company (TCCC) based in the United States; and consumers, the general public, news media, politicians or other stakeholder groups tend not to differentiate between legal entities - for them, Coke is Coke. Thus, substantial criticism is not only directed at the Indian firm but at the TCCC as well, which of course is strongly concerned about its investment in one of the fastest-growing markets in Asia. In addition, many national Coca-Cola companies, for example in North America and Europe, have had to answer questions and criticism from consumers and activist NGOs in their respective countries, and even faced boycott threats thousands of kilometres away from India.

The challenge for TCCC is to protect its world-wide brand image and corporate reputation, and to confront economic and innovation problems in a very competitive environment. This case is a classic example of the importance of CSR and the admonition "think global" even where local decisions and action matter most. External pressure and demands for change may, however, create an opportunity to find and implement innovative advantage. 


\section{A decade of disputes}

Water disputes between Coca-Cola India's bottling plants and their surrounding communities have at least ten years of history. As protesting farmers and villages organized and mobilized, regional governments and finally the federal government and parliament got into the act, and so did lawyers, scientists, NGOs and major Indian media. Conflicts about water were often mixed with other issues such as industrial pollution and toxic waste, or charges that Coca-Cola consumer products contain pesticides, leading to the moniker "Pesticola." In 2003, the New Delhi Centre for Science and Environment examined a number of nonalcoholic beverages and claimed that nine out of 12 soft drink samples produced by Coca-Cola and PepsiCo operators in India failed to meet EU (not Indian) safety standards for pesticide residue (Hills \& Welford, 2005, p.170). Public reaction was harsh despite strong company denials. Several Indian states and localities prohibited sales of Coke and Pepsi in schools during the pesticide scare; when the soft drink groups, which had made a broad PR effort including counter-claim advertising, finally calmed the protests and got bans of their products lifted, they discovered the national government capitalized on negative public opinion to campaign for a junk food ban, again penalizing Coca-Cola and its peers in the industry (Johnson, 2006).

This article will concentrate on water issues, but it should be kept in mind that a combination with other much-discussed problems and negative publicity marked many controversies.

Controversy first turned into high pitch conflict in the state of Kerala in Southwest India. Protesting farmers in the Plachimada village held that their rice and coconut production fell sharply after a new Coca-Cola bottling plant went into operation and drew too much ground water. While the state had defended the company, a court found the plant guilty of environmental damage, ordered it to stop water extraction (which was at about half a million litres per day), effectively shutting down the plan, and ordered government to enforce the ruling (Brown, 2003). CocaCola India had unsuccessfully tried to make the argument that it was not the bottling plant that caused the water shortage, but that the area had a lack of rainfall (Hills \& Welford, 2005, p.171).

The next three years saw CCI run the gauntlet of attacks from Indian NGOs, local councils and politicians in many places to shut down bottle plants. CCI fought back with lawsuits and won major legal battles, but then protests started in North America and in Europe. Boycotts were initiated, universities cancelled cafeteria contracts. It did not matter that CCI was able to prove that local water shortages were predominantly caused by decreased rainfall. What stuck were internationally broadcast TV images of thousands of Indian locals marching against the company, and non-violent protesters, among them many women, being clubbed, injured and arrested by police. That certainly did not help to improve the soda maker's popularity. Coca-Cola committed to better dialogue with local communities and water experts, financing rural water management and investing in innovations like advanced rainwater harvesting technology; it promised to become "a net contributor of water". But these initiatives did not quite get the echo the company had wanted; after escalation of the conflicts, NGOs seemed unwilling to communicate with managers (Hills \& Welford, 2005, p.168-170).

In June 2005, the issue made it to the front page of the Wall Street Journal The paper publicized "How a global web of activists gives coke problems in India," showcasing the highly successful work of a sole Indian-born activist in California running a website, indiaresource.org. The Journal pondered the fact that

a one-man NGO armed with just a laptop computer, a Web site and a telephone calling card can, with his allies, influence a huge multi- national corporation illustrates the role social activists can play in a world that's going increasingly online. (Stecklow, 2005)

Pressure mounted, protesters continued to march, and the antiCoca-Cola movement did not vanish despite the company’s legal successes. CCI managed to reduce its water use ratios in India by 24 percent between 2000 and 2004 and further in the following years. Rainwater harvesting systems were now installed in all bottling plants; CCI pointed out that its quality standards not only met but often exceeded applicable laws and that much of the water used in operations was renewed, replenished and returned to groundwater systems (Hills \& Welford, 2005, pp. 300-301) Meanwhile, fights in court continued. In 2010, the Indian High Court ruled that the bottling plant in Plachimada remains shut down, and CCI was held liable for US\$ 48 million for locally caused damage (Global Research, 2010).

Coca-Cola, it should be noted, has stood for years at the forefront of attacks, while rivals such as PepsiCo, which long led Coke in sales in India, have largely been spared. By comparison, of course, Coke's brand is much stronger, and its prominence seems to be a very inviting target and symbol to mobilize against.

In analysis, CCI has much blame to place on itself. Bent on fast expansion in the quickly growing Indian consumer market and welcome as an industrial investor by rural economic administrators, CCI did not, in the beginning, engage much in communication with local people. It did not take water concerns seriously. The firm's answer to people's intense questioning was denial, then legal proceedings. It did not try to change their water use practices until practically it was forced to do so. Pressure from outside forced the firm to become more innovative. But one has to keep in mind that CCI also recognized the economic incentive of better sustainability and stewardship: Water shortages can dry up the plants. It remains unclear how much water the Coca-Cola plants really use; scientific estimates by experts and critical NGOs vary greatly, and company representatives, in defense, have usually presented much lower consumption data than what their accusants have claimed. Compared with what its parent company in Atlanta provides online on global water use data, CCI communications and documentation look rather amateurish and unconvincing in presentation.

In any case, CCI failed to engage in trust-building with the public when it still had the chance, and the escalating public controversy destroyed much of the trust and credibility that was there. Even though CCI responded to the pressure with a CSRinspired program for water conservation and management, of course India remains a country where many regions do have a general water problem. Furthermore governmental regulations are very weak. Public and media outrage has often been fuelled by government actors taking a stance for the Coca-Cola operators. The blame for harsh police reactions to demonstrations, however, went home with Coca-Cola rather than the government. Local community complaints and protests continue even today in 2013, and whether proven or not, often local perception is widespread that water shortages, when they occur, have something to do with the beverage making facilities. This is unlikely to go away, as the plants do draw enormous volumes of groundwater from local wells.

\section{Improving responsibility}

Rebuilding trust can only work if Coca-Cola delivers on its promises and makes a convincing case to local communities and water authorities that resources are used responsibly. The firm and its licensed bottling partners should be given credit for its systematic development of water sustainability projects, im- 
proved water replenishment and reduced water use ratios by increasing efficiency and decreasing waste water.

Corporate social responsibility can answer social, environmental, and economic challenges partly by better decision-making and business processes, but also by innovation. Finding creative solutions while cooperating with stakeholders protects the business. Coca-Cola still considers India one of its major growth markets and sees much potential there; TCCC and CCI have already invested \$2 billion into India operations in the past two decades and have committed to investing another US\$5 billion until 2020 (Gulati \& Ahmed, 2012). To realize the potential, Coca-Cola has to ensure the water issues do not become obstacles for market growth.

Since the mid-2000s, the parent company has undertaken a major global effort to make "water stewardship" a hallmark of its operation. TCCC emphasizes that protecting local water sources is in its immediate own vested interest because its products are produced and sold locally. Mitigating water-related risks, local source vulnerability assessments, and source water protection plans mandatory by all bottling plants are among the action taken globally. The TCCC has been laying out water efficiency plans until 2020, based on broad data analysis, most of which has centered on developing markets. Local community partnerships with India featuring prominently - but also global partnerships have become staples of the TCCC's water stewardship communications.

For example, TCCC is a partner of the CEO Water Mandate which is an initiative of the UN Global Leadership Forum that is "designed to help companies better manage water use in their direct operations and throughout their supply chain" (Lambooy, 2011, p. 857). A worldwide collaborative partnership for seven world river basin projects with the environmental organization WWF is part of that, although it should be noted that no project in India was among them. CCI is engaging in a number of community access to water and sanitation through India, going back to a $2007 \mathrm{CCI} / \mathrm{UN}$ Habitat agreement. It includes demonstration projects which supply water to several poor areas (Elks, 2012). In 2009, TCCC implemented a CSR campaign, "Live Positively". The aim is "to set initiatives that create positive change in the world through sustainability;" one core goal is sustainable water use (Elks, 2012). An "International World Water Day" has been proclaimed in cooperation with associates of bottling units, local NGOs, community leaders and other significant stakeholders with the aim to generate awareness about Water Conservation (CCI, 2010a).

The list of water-related activities by Coca-Cola both globally and in India is, at first sight, quite impressive. But at closer inspection, the general sustainability programs do not seem to contribute much directly to solving the actual problem that evidence still points to farmers' decreasing water supply in the vicinity of Coca-Cola bottling plants in dry areas.

This raises questions about whether the sustainability approach of CCI and TCCC really makes a difference for adversely affected local farming communities. An initiative that creates longterm water access for the farmers would be supportive for the agriculture within the rounded area - for example, CCI could provide free water access for all farmers using its much better technical capabilities to reach the ground water deposit. The risk and costs of implementing a free-access policy could be high. Next to the obvious technical costs for providing water, a range of new problems may arise, not the least with overuse, wastewater, and unclear legal and technical responsibilities for the general local water management. Under a "free water powered by Coke" scenario, there would be the need of having a strict set of rules and a strong collaboration with government. Assuming such responsibility clearly has its downsides, even if the community would welcome it. And even if such a model could be worked out, in the background is the risk (including a legal one) that Coca-Cola would, at least indirectly, admit that the plants' operations have something to do with the water shortages in the first place.

On the one hand, TCCC water stewardship activities benefit not only the parent and global reputation but also the CCI. They create a framework of water use responsibility. Awareness of the water scarcity increases globally, and Coca-Cola's initiatives probably softened some reproachful negative attitudes toward the firms. However, a "Live Positively" CSR campaign, or some national or regional CSR campaigns in India - which even have public relations and CSR awards - may lack a direct positive impact for the farmers living close to the bottling plants. Only concrete local action contributes to positive solutions, and such efforts seem not yet to be satisfactorily implemented across the several dozen Indian bottling plants.

It is, then, understandable that local communities and NGOs are still skeptical and critical, and that Coca-Cola's recent CSR activities look to some more like a "Marketing 3.0" or a "greenwashing initiative" (FFFM, 2011). With a decade full of accusations, negative news reporting, government and court proceedings, and seemingly unlimited anti-Coca-Cola opinion-making across the Internet, from NGO websites to videos to social media activism, it will be a very long road until a critical public will return to "normal" relations with Coca-Cola in India - and beyond.

\section{Conclusions}

Although coming late, Coca-Cola's water initiatives have been moving in the right direction, both globally and in India. While there is much room for improvement and for connecting the initiatives at the several levels of possible CSR action, important steps have been taken.

Locally, communities in India will measure the credibility of Coca-Cola's promises by the practical response to water shortages when they occur - for whatever reason. It remains to be seen whether public acceptance and trust will grow substantially. The company's behavior will certainly be always be under scrutiny. Stakeholders pay attention, and so should the managers.

At a higher level in India, company managers will likely have other regulatory and legal battles to fight in the future, not only on water but on other social, health, and environmental issues. Managers will know that ten years' worth of water controversy loom large in the background, and public and policy-makers may long remember this.

In India, Coca-Cola has learned the hard way about its local and its global responsibilities. It is not a coincidence that the parent company began to seriously engage with global water stewardship after the critical experience in India in the early to mid-2000s. That market India always had a special place for the firm's global growth strategy, so the lessons learned there received high attention on the other side of the world. It may be a distance of 15,000 kilometres between the village of Plachimada and Atlanta, but the impact of the local conflict was surely felt at Coca-Cola's world headquarters. It would have been unwise to leave problem-solving only to the national subsidiary, as CocaCola faces water management challenges in many other places. But it should be remembered that no other cases have had the same kind of attention as the ones in India, and that it was the Indian ones that sparked harsh criticism in developed markets.

That Western attention has, of course, much decreased. The water issues are back to a more national/regional concern, which is where practical solutions have to be applied and where CocaCola has to meet its community stakeholders' needs. 


\section{References}

Brown, P. (2003, 19 Dec). Coca-Cola plant must stop draining water: Indian bottling factory may be forced to close after judge orders ban to protect village's supply. The Guardian. Retrieved 2 Nov 2013 from http://www.theguardian.com/world/2003/dec/19/india.sciencenews

Burnett, M. and Welford, R. (2007), Case study: Coca-Cola and water in India: episode 2. Corporate Social Responsibility and Environmental Management, 14: 298-304. doi: 10.1002/csr.157

Coca-Cola India (2010), Sustainability Report. Retrieved 30 January 2013 from http://www.cocacolaindia.com/CMS/Asset/environment_Report_2010.pdf

Coca-Cola India (2010a). Press release. Stakeholders recognize CCI Efforts retrieved on 30 January 2013 from http://www.cocacolaindia.com/presscenter/wwd.html

Coca-Cola India (2010b). Awards. The Coca-Cola System in India celebrates World Water Day. Retrieved 30 January 2013 from http://www.cocacolaindia.com/presscenter/stakeholders_recognize_CCI_efforts.html

Elks, J. (2012). Sustainable brands. Coca-Cola gives back, helps the world live positively. Retrieved 30 January 2013 from http://www.sustainablebrands.com/news_and_views/blog/coca-colagives-back-helps-world-live-positively

Environment News Service (2007). WWF and Coca-Cola embark on water conservation initiative. Retrieved on 30 January 2013 from http://www.ens-newswire.com/ens/jun2007/2007-06-05-07.asp

Forum from Future Marketing (2011). Seminar SS11. Coca-Cola - LIVE POSITIVELYТ ${ }^{\mathrm{TM}}$ ? Retrieved 30 January 2013 from http://www.360m.de/2011/coca-cola- percentE2 percent80 percent93live-positively percentE2 percent84 percentA2/

Global Research (2010). Coca-Cola causes serious depletion of water resources in India. Retrieved 30 January 2013 from http://www.globalresearch.ca/coca-cola-causes-serious-depletion-ofwater-resources-in-india/18305

Gulati, N. \& Ahmed, R. (2012, 13 July). India has 1.2 billion people but not enough drink Coke. Wall Street Journal. Retrieved 30 January 2013 from

http://online.wsj.com/news/articles/SB10001424052702304870304577 490092413939410

Hills, J. \& Welford, R. (2005). Coca-Cola and water in India. Corporate Social Responsibility and Environmental Managemen, 12: 168-177. doi: $10.1002 / \mathrm{csr} .97$

India Resource Center (2011). Deception with purpose: Pepsico's water claims in India. Retrieved 30 January 2013 from http://www.indiaresource.org/news/2011/pepsipositivewater.html

International Water Management Institute (2006). Insights from the comprehensive assessment of water management in agriculture. comprehensive assessment. Retrieved 30 January 2013 from http://news.bbc.co.uk/2/shared/bsp/hi/pdfs/21_08_06_world_water_we ek.pdf

Johnson, J. (2006, 16 December). India strives for junk food ban in schools. Financial Times. Retrieved 2 November 2013 from http://www.ft.com/cms/s/0/bfbd9458-8cae-11db-96840000779e2340.html

Lambooy, T. (2011, May). Corporate social responsibility: sustainable water use. Journal of Cleaner Production 19(8), 852-866. DOI 10.1016/j.jclepro.2010.09.009.

Rose, M. B., \& Bolton, B. (2004). Coca-cola or clean water? Sojourners Magazine, 33, 10-10. Retrieved 30 January 2013 from http://search.proquest.com/docview/212840619?accountid=14620 